\title{
Problems and Solutions to Alleviate Poverty in Nepal
}

-Dr. Badri Narayan Sah*

\begin{abstract}
Poverty is one of the main problems in Nepal. In order to alleviate poverty, various attempts have been implemented for poverty reduction. As per the policies of the periodic plan that started six decades ago, different programmes are conducted. Both national as well as international organizations are carrying out research activities to alleviate poverty. According to the $9^{\text {th }}$ plan (1997-2002), the percent of population under poverty line was 38 percent which was aimed to reduce to 30 percent as per the $10^{\text {th }}$ plan (2002-2007) but remained unsuccessful. While in the $12^{\text {th }}$ plan (2012-2017) the percent of population under the poverty line was successfully reduced to 25.2 percent. According to the NLSS survey report the percent of population under the poverty line in the year 1995/96, 2003/04 and 2010/11 was 41.8 percent, 30.9 percent and 25.2 percent respectively. With long term economic growth, poverty, inequality and unemployment can be eliminated. But it is definitely a challenge. However, the $13^{\text {th }}$ plan (2070/71-2072/73) and $14^{\text {th }}$ plan (2073/742075/76) reduced the poverty percent to 21.6 percent and 18.7 percent respectively. Similarly, the 15th plan (2076/77-2080/81) targeted to reduce the poverty from 18.7 percent to 11.0 percent. Finally, poverty is assumed to be zero by the year 2100/01 (NPC $15^{\text {th }}$ Plan 2076/77-2080/81). But this is a big challenge due to Covid-19 pandemic and its second wave because Nepalese living below the poverty line are highly vulnerable due to covid pandemic.
\end{abstract}

Keywords: Poverty, problems, planned, challenges, unemployment, solutions.

\section{Introduction}

Poverty is one of the major topics to discuss in Nepal. The country has been facing poverty since a long time. Although there are different measures taken to improve the situation of people and reduce poverty; however, a successful outcome is not achieved yet. Around twothird of the population of Nepal is still dependent on agriculture (MOF 2077/78). Since agriculture is seasonal, it depends on monsoon resulting in less production. So, modernizing the agricultural sector is necessary in order to benefit the people of rural community and observe an increase in country’s economy.

*Dr. Sah is an assistant professor of Economics, Patan Multiple Campus, TU, Nepal. 
To understand poverty and its consequences, conducting investigation and doing measurements is not enough. The condition of people in a particular area clearly depicts the occurrence of poverty. It cannot be hidden. Basic personal needs such as food, clothing, and shelter are not fulfilled in such condition. Also, the terms that describe poverty in Nepal are bipanna, daridra, dukhi, nimcharo, nimukha, nirdhan, nirdho, sukumbasi, bhoka-nanga, kangal, anikale, bhikari, bhokmari, dinahin etc. While the antonyms to poverty are dhani, amir, saahu, punjipati, jamindar, malik, swami, raja saheb, hunekhane, pahuchwal, jannesunne, thula-bada, hakim sukhi, hukumbasi etc.

Due to the outbreak of the Covid-19 (corona virus pandemic) in 2020, the economy was heavily affected. The world economy decreased by 3.3 percent (MOF 2077/78). Nepal's economy decreased by 2.1 percent in 2076/77 (MOF 2076/77). The economic deterioration caused by this outbreak is expected to be 4.0 percent in the fiscal year 2077/78 (MOF 2077/78).

The per capita income increased the Gross Domestic Product (GDP) from US \$1126 in 2076/77 to US $\$ 1191$ in 2077/78 (MOF 2077/78). This increase took place by 5.8 percent (MOF 2077/78). Likewise, the first sector, second sector and third sector will subsequently have an economic growth rate of 2.6 percent, 5.0 percent and 4.4 percent respectively (MOF 2077/78). Also, the contribution from these sectors to the GDP of the country is estimated to be 25.8 percent, 13.1 percent and 61.1 percent respectively in 2077/78 (MOF 2077/78). The absolute poverty was 18.7 percent in 2074/75 which is assumed to be around 16.7 percent in 2076/77 (MOF 2076/77). But decreasing the absolute poverty to 10 percent in 2080/81 is challenging (MOF 2077/78). With the production and distribution of vaccines for Covid-19, there is an increase in the economic activities all over the world. Also, it is expected that the world economy will increase by 6.0 percent in 2021 (MOF 2077/78).

The remittance flow of the country until Falgun 2077/78 increased by 8.6 percent (MOF 2077/78). This remittance flow into the country until Falgun 2076/77 had increased by 1.8 percent while previously it was 23.4 percent. This rate decreased due to the Covid-19 pandemic. Until the end of the fiscal year 2076/77, around 12,25,000 families were surveyed for multidimensional poverty measurement (MOF 2076/77). From the data 3,91,831 families were found to be below the poverty line. Similarly, the data collection until the end of Falgun2077/78 identified that there are 11,50,000 poverty households in 23 districts (MOF 2077/78). Hence, before the outbreak, the efforts to alleviate poverty with necessary programmes and initiations were quite successful. But with the occurrence of Covid-19, the economic factors are heavily affected, impacting poverty and worsening the life of the poor. In addition, the contribution of the non-agricultural sector and agricultural sector in 2077/78 was 74.2 percent and 25.8 percent respectively (MOF 2077/78). While the 
contributions to the total GDP of the country from agricultural and non-agricultural sector was 26.2 percent and 73.8 percent in 2076/77 (MOF 2077/78).

\section{Objectives of the Study}

The main objectives of the study are;

1. To find out the major problems of poverty alleviation in Nepal;

2. To find out the solutions for poverty alleviation.

\section{Methodology}

The study is mainly based on secondary sources of information and study approaches are analytical and descriptive. The data used in this study are published in journals, newspapers, books, government as well as international publications. Government publications include various issues of economic survey of the Ministry of Finance, Nepal Living Standard Survey conducted by the Central Bureau of Statistics, various plans and period documents of the National Planning Commission, Nepal Rastra Bank Bulletin and published reports of international organizations such as ADB, DFID, IMF, UNDP, WB and WTO. Collected data and reports play a vital role in the analysis of poverty. Such analysis will be helpful when carrying out poverty alleviation programmes.

\section{Problems of Poverty}

Poverty is heavily associated with agriculture in Nepal. On one hand, around two-third of Nepal's population relies on agriculture for their livelihood while the agricultural production has significantly reduced. So, when the economy is not much benefitted from agricultural sector, the people dependent on it are facing financial crisis. Therefore, in order to alleviate poverty proper policies, programmes need to be implemented. The main problems of poverty are:

1. Unable to recognize poor families and households.

2. Social protection activities not targeted to poor families.

3. Unable to establish proper co-ordination between the conducted programmes.

4. Inadequate capacity building programmes for the needy.

5. Lack of proper co-ordination between the policies, planning and budgeting of the related programmes.

6. Rather than providing skill to the people, programmes are distribution oriented.

7. Inability in organizing actual poverty alleviation programmes.

8. Occurrence of subsistence agriculture.

9. Inaccessibility of the poor people to the country's resources and equipment. 
10. Unable to use the remittance entering the country for productive production and development.

11. Losing the young youths through foreign employment.

12. Lack of employment opportunity in spite of having skill and education.

\section{Review of Literature}

NPC (2018) study report presented that 28.6 percent of the Nepalese were suffering from multidimensional poverty. 7 percent of the urban and 33 percent of the rural population face multidimensional poverty in Nepal. The studies find out that province 2 and 6 have the highest rate of poverty. The report is mainly divided into three sections; (i) Monetary poverty measurement in Nepal, (ii) Multidimensional poverty measurement in Nepal and (iii) The purpose of Nepal's multidimensional poverty index (MPI). The study highlighted that about 80 percent of the Nepalese population would reside in rural areas in 2014. More than 90 percent of the multidimensionally poor people live in rural area while the remaining 5 percent of the country's population resides in urban areas. Hence 95 percent of Nepalese people live in rural areas.

WB (2017) report focused on reducing poverty in rural areas of Nepal, especially among communities. The objectives were aligned with Nepal's poverty reduction strategy. The study also focused on the social inclusion of marginalized groups such as women, dalit and ethnic minorities. Nepal's poverty alleviation fund is one of the several long standing WB assisting community driven development projects. In this context Nepal's most important development challenges were (i) reduction of high level of poverty, (ii) slow economic growth, (iii) social inclusion (iv) increasing inequality and (v) poor governance. The study also explained that poverty in Nepal is mainly rural phenomenon, because 85 percent of the people lived in rural and remote areas and were dependent predominantly on agriculture. The main objectives of the study were (i) improving access to income generating subprojects and (ii) improving access to community infrastructure. So, income generating subprojects require complementary activities such as specific training and support to access markets.

Nikku Bala and Azman Azlinda (2014) stated, the systematic drive for national economic development begun in 1956, when the National Planning Commission and Nepal Rastra bank were established. The National Planning Commission drafted and introduced the first five-yearplan (1956-1961) under a very unfavorable situation. The situation characterized by mass illiteracy, high mortality and fertility rates, high incidence of endemic disease, almost no physical infrastructures including lack of skilled manpower and severe financial constraints. Poverty alleviation has always been an overriding concern of Nepal's development planning exercises, but only since the sixth plan (1981-1985) has it been 
explicitly stated as a development objective. The study is divided into seven sections; (i) Introduction, (ii) Nepal: a country in transition, (iii) Poverty studies and measurements: a brief conceptual outline, (iv) Micro impact of the macro and adjustment policies (MIMAP), (v) Poverty in development plans of Nepal, (vi) Experiments with poverty eradication and, (vii) Way forward: the pronged approach. The study also stated Nepal's achievement in addressing poverty are notable given the country's politically difficult and conflict-ridden environment in the last two decades.

ADB (2013) elaborated NLSS I, NLSS II and NLSS III findings in different ecological regions. The National Living Standard Survey (NLSS) conducted in 1996, 2004 and 2011 by Central Bureau of Statistics. According to the surveys, poverty incidence has been falling from 41.8 percent to 30.9 percent between 1996 and 2004, and 30.9 percent to 25.2 percent in 2011. In Nepal, the incidence of rural poverty is higher than urban Nepal. Urban poverty fell from 21.6 percent in 1996 to 10.0 percent in 2004, but it again rose to 15.5 percent in 2011. Rural poverty has declined continuously from 43.3 percent to 35.0 percent and to 27.4 percent in 1996, 2004 and 2011 respectively. The research focused on the impacts for reducing the poverty and also on the human development indicators which are; (i) increase in remittance (ii) growth in agriculture sector and rise in farm income (iii) main focus in planned development on poverty reduction (iv) greater access to rural finance and increase in micro finance institutions (v) growth in human capital development and (vi) increase in access to infrastructure such as roads, schools, health posts, hospitals, public transportations, marketing and financial facilities.

WB (2012) investigated the design and result of an impact evaluation of the Nepal Poverty Alleviation Fund programme. In this study, there were two rounds of survey data (pre and post intervention) and difference-in-difference approach combined with instrumental variables estimation method. The study research highlighted to evidence on social funds evaluation in three ways; (i) use an experimental design and evaluate the impact of a largescale intervention (ii) estimate the casual impact even when there is no perfect compliance between the actual interventions and the randomized assignment and (iii) using per capita households' consumption, impact on food security and important indicators of vulnerability in conflict setting.

IMF (2003) studied poverty reduction strategy paper, the tenth plan (2002-2007) in Nepal. The paper organized introduction, the socio-political and economic context in Section I. The paper also begins with a brief discussion of the tenth plan's preparation process and key elements such as country ownership, particularly preparation and the dissemination and feedback process including all key segments of the Nepali public in Section II. Section III reviews the development efforts undertaken in the recent past through the ninth plan 
(1997/98-2001/02). Section IV discusses on the dimensions of Nepal's poverty problems, manifestations and determinants and linkages with the ongoing social disorder. Similarly, the outline of the poverty reduction strategy of the tenth plan is discussed in Section V. In Section VI macro-economic framework programmes, and activities and programme required to be implemented from time to time have been focused. Besides, implementation, monitoring and evaluation modalities which are necessary to ensure effective implementation of the plan and key tools and instruments used in this regard are discussed in section VII. Hence the plan has focused on effective implementation and monitory mechanism.

\section{Regions-Specific Poverty Indicators}

Poverty and its impact vary in different regions of Nepal. The urban area is less affected by poverty whereas the rural areas are highly affected. The effect of poverty in urban areas is 15.5 percent while in rural areas it is 27.4 percent. Similarly, its effect in the Mountain, Hilly and Terai region is 42.3 percent, 24.3 percent and 23.4 percent respectively in 2010/11(Table 1). Due to the availability of goods, services and opportunities, the people of urban areas are relatively less impacted by poverty. This kind of availability is not found in rural areas. Therefore, until the end of the $9^{\text {th }}$ plan the poverty will be alleviated from 42 percent to 38 percent in Nepal.

NLSS 2003/04 estimated the population below poverty line in 2004 to be 31 percent. It is declined by 11 percent from 42 percent in 1995/96. The rural areas poverty decline was 9 percent (from 43.3 to 34.6 percent) in 1995/96 and 2003/04 respectively. Similarly, 12 percent (from 21.6 to 9.6 percent) decline in urban areas in 1995/96 and 2003/04 respectively. In 2010/11 about one quarter of the population lived below poverty line. The poverty decline rate during this period is 1.4 percent every year. A comparison of poverty level between the rural and urban sector estimates 43 to 35 and 22 to 10 percent in 1995/96 and 2003/04 respectively. It has declined by 8 and 12 percent in rural as well as urban sector. Similarly, poverty level between the rural and urban sector estimates 35 to 27 and 10 to 16 percent in 2003/04 and 2010/11 respectively. It has declined by 10 percent and increased by 6 percent in rural as well as urban sector.

Table 1: Poverty Incidence by Regional Basis

\begin{tabular}{|l|c|c|c|}
\hline \multirow{2}{*}{ Geographical regions } & \multicolumn{3}{|c|}{ Poverty calculation rate (\%) } \\
\cline { 2 - 4 } & $\mathbf{1 9 9 5 / 9 6}$ & $\mathbf{2 0 0 3 / 0 4}$ & $\mathbf{2 0 1 0 / 1 1}$ \\
\hline Regions & & & \\
\hline Urban & 21.6 & 9.6 & 15.5 \\
\hline
\end{tabular}




\begin{tabular}{|c|c|c|c|}
\hline Rural & 43.3 & 34.6 & 27.4 \\
\hline \multicolumn{4}{|l|}{ Other Regions } \\
\hline Kathmandu & 4.3 & 3.3 & 11.5 \\
\hline Others urban & 31.6 & 13.0 & 8.7 \\
\hline Rural Western Hll & 55.0 & 37.4 & 28.0 \\
\hline Rural Eastern Hill & 36.1 & 42.9 & 15.1 \\
\hline Rural Western Terai & 46.1 & 38.1 & 22.3 \\
\hline Rural Eastern Terai & 37.3 & 24.9 & 21.0 \\
\hline \multicolumn{4}{|c|}{ Development Regions } \\
\hline Eastern & 38.9 & 29.3 & 21.4 \\
\hline Central & 32.5 & 27.1 & 21.7 \\
\hline Western & 38.5 & 27.1 & 22.2 \\
\hline Mid-western & 59.9 & 44.8 & 31.7 \\
\hline Far-western & 63.9 & 41.0 & 45.6 \\
\hline \multicolumn{4}{|l|}{ Ecological regions } \\
\hline Mountain & 57.0 & 32.6 & 42.3 \\
\hline Hill & 40.7 & 34.5 & 24.3 \\
\hline Terai & 40.3 & 27.6 & 23.4 \\
\hline Nepal & 41.8 & 30.9 & 25.2 \\
\hline
\end{tabular}

Source: CBS 2011.

From 1995/96, 2003/04 and 2010/11, the various indicators of poverty and inequality showed no significant decrease in the factors. Poverty reduction was more in urban areas as compared to rural. Hence there exists s strong and intensive impact of poverty in the rural areas.

Poverty in Nepal according to geographical areas have been shown in the figure below. Figure 1 shows the poverty incidence in urban and rural areas of Nepal. Figure 2 shows the poverty incidence by ecological belt that includes Mountain, Hilly and Terai region. 

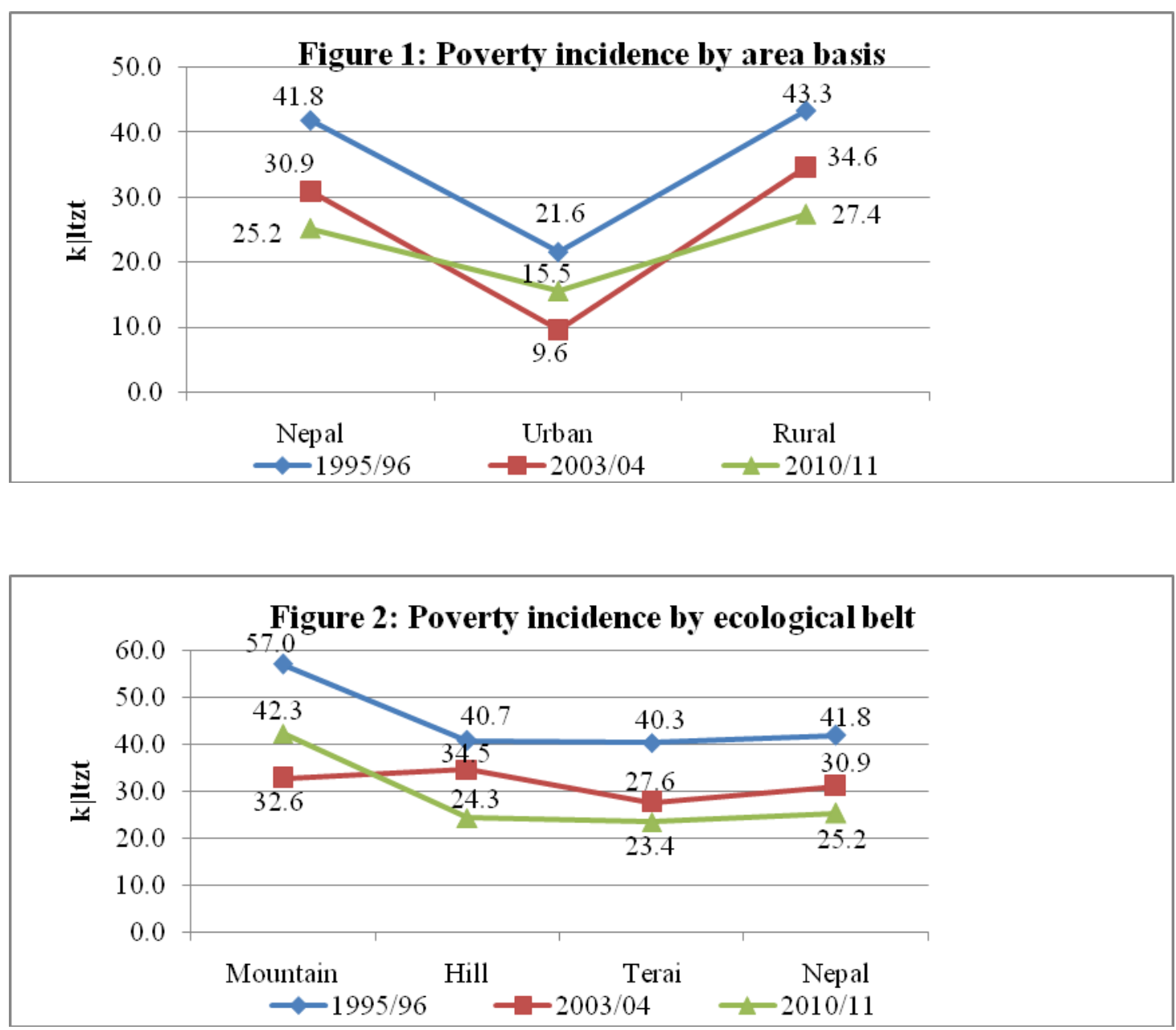

Source: CBS 2011.

\section{Causes of Poverty}

The socio-economic processes in Nepal have not contributed to the reduction of poverty. While the main causes are listed below:

1. Traditional poverty: Numerous families and their ancestors have been facing poverty since a long time back. Their ancestors faced poverty and now they are facing it too. These people are not able to afford for better facilities and services, and bring change into their lives. Hence this tradition continues from generation to generation, and they constantly fight poverty and hunger.

2. Exploitation and deceiving: The poor people are subjected to exploitation by the capitalists, landholders and are fooled by them. The rich people fool them and take away whatever little they have. They are obliged to sell their property in low price 
and face unimaginable circumstances. Therefore, the general public can never progress from the position holders present in the society.

3. Loan and high interest rate: Most of the helpless people in Nepal take loans in order to start a business or invest in something that can help them earn a livelihood. But they are unable to pay the loan in time. As a result, the loan amount increases than what it was before. Then their children have the pressure of paying the loan amount. Because of the increased interest rate imposed by the merchant and proprietors, the poor people are condemned to pay whatever they have.

4. Population growth rate: The population growth rate of Nepal according to census 2058 data was 2.25 percent whereas in census 2068 it was 1.4 percent. Although the growth rate seems to be decreasing, the labour force value remains unchanged.

5. Lack of education: The literacy rate of Nepal in census 2068 was 65.9 percent in which the male and the female literacy rate were 75.1 and 57.4 percent respectively. According to the research in 2068, more people were literate in Kathmandu with a literacy rate of 86.3 percent while less people were literate in Rautahat with a literacy rate of 41.7 percent. This indicates that literacy rate among people living in urban areas is higher than in rural areas. Therefore, poverty has affected the people of rural areas due to the lack of education.

6. Lack of skill and employment opportunities: Majority of population (83 percent, census 2068) still resides in villages; rural areas and their main occupation is still agriculture. Lack of skill and employment opportunities are the main causes they are facing poverty.

7. Others: The country's geographical structure, seasonal agriculture, lack of labour market, unemployment situation and lack of strong government policies and lazy behaviour are the other causes of poverty.

Besides, gender inequality and dependency ratio are also main causes of the poverty alleviation in Nepal (Figure 3). 


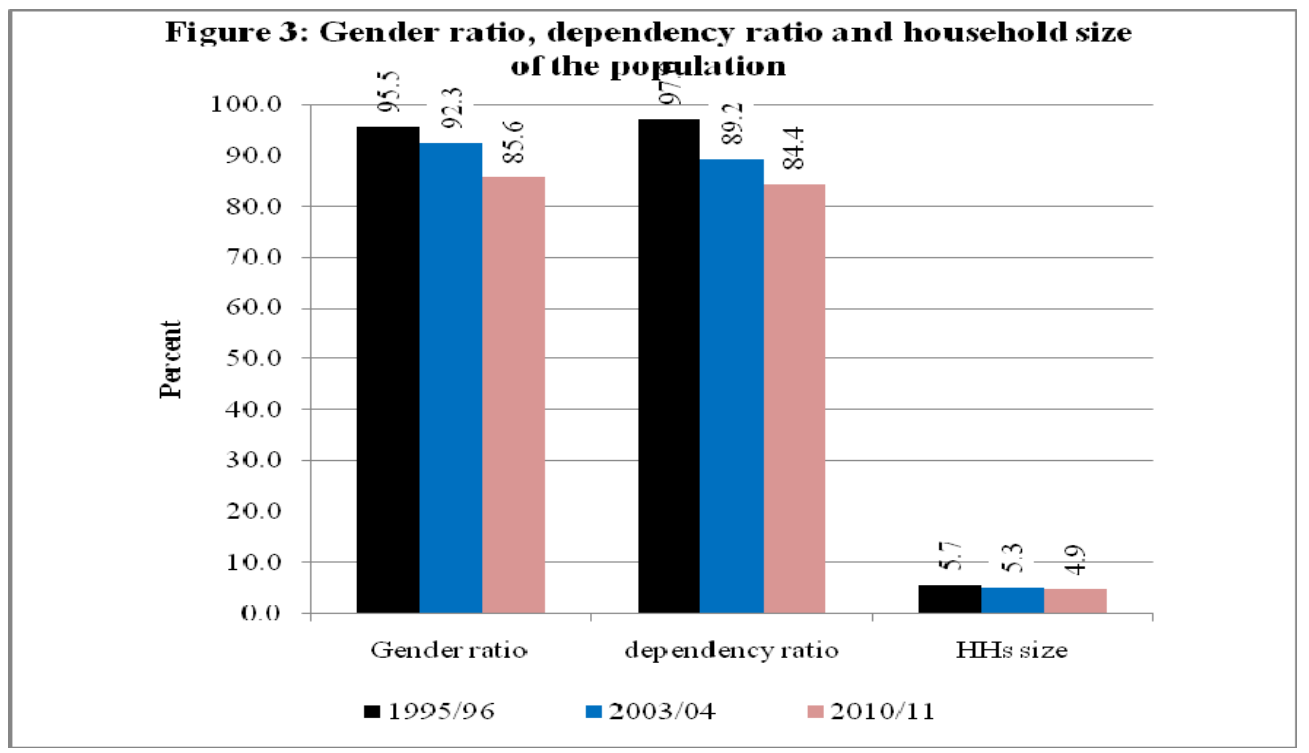

Source: CBS 2011.

\section{Challenges}

In spite of having different solutions to alleviate poverty in Nepal, challenges still prevail in the society. The country is not able to obtain satisfying results in eradicating poverty completely. Right from the start of introducing planned policies, there are numerous attempts executed in order to alleviate poverty. Especially after the execution of the $9^{\text {th }}$ plan the efforts for the eradication were quite effective. Though this topic seems to be associated more with the government sector but other sectors apart from the government sector play a vital role as well.

Even though the percent of population below poverty line seems to be decreasing these days, large number of people in the rural community are still affected by it. Females, aboriginals and minorities living in rural areas are the ones heavily affected. Therefore, searching for the solutions and implementing them is very important. In addition, diminishing the inequality and the gap between the rich and the poor and establishing economic welfare is essential. The challenges faced are as follows:

1. Unstable economic growth rate.

2. Lack of village-oriented programmes for economic development.

3. Lack of proper deposit in productive sector from financial sector.

4. Unable to increase growth in the total GDP.

5. Growing inequality between the urban and rural areas.

6. Unable to maintain equality and stability between the poor classified by geography, gender and ethnicity. 
7. Providing access to the poor for skill development, capital and technology.

8. Modernizing and commercializing the agricultural sector.

9. Unable to create investment-oriented environment.

10. Creating employment opportunity in the field of agriculture, industry and tourism.

11. Unable to recognize actual poverty and conduct alleviation programmes.

\section{Efforts to Solve Poverty in Different Plan Period}

The governmental sector, non-governmental sector and international organizations in Nepal are repeatedly publishing poverty related indexes through various researches and investigations. According to the report published by National Planning Commission in 1976, 36 percent of the total population was below the poverty line. Likewise, the household survey conducted by Nepal Rastra Bank in 1984 concluded that the percent of population below poverty line was 41.5 percent. The report of the $8^{\text {th }}$ plan published by National Planning Commission in (2049-2054) showed the poverty percent to be 49 percent. Similarly, the report published by National Federal Development Association concluded it to be 52percent. Therefore, the $9^{\text {th }}$ plan focused on reducing the poverty percent to 32 (Table 2).

Table 2: Targeted below poverty programme in ninth plan period

\begin{tabular}{|l|c|c|}
\hline Plan period & $\begin{array}{c}\text { Targeted below poverty } \\
\text { population (\%) }\end{array}$ & Remarks \\
\hline Begin in ninth plan (1997) & 42.0 & \\
\hline End of ninth plan (2002) & 32.0 & $\begin{array}{c}\text { Estimated, while found } \\
\text { to be 38 \% only }\end{array}$ \\
\hline End of tenth plan (2002-2007)) & 23.0 & \\
\hline End of eleventh plan (2007-2012) & 15.0 & \\
\hline End of twelve plan (2012-2017) & 10.0 & \\
\hline
\end{tabular}

Source: Ninth plan (1997-2002), NPC, Kathmandu, Nepal.

Although the $9^{\text {th }}$ plan stated that the percent of population below poverty would be reduced to 32, this wasn't successful enough and the result was found to be 38 percent. Along with this, the $10^{\text {th }}, 11^{\text {th }}$ and the $12^{\text {th }}$ plan too remained incomplete and unsuccessful. During this time the political matters and its ups and downs were given more priority instead of the national economic development. So, many important economic indexes didn't have an expected progress and remained as it is.

In the $13^{\text {th }}$ plan, various economic indexes have been brought together and the percent of population below poverty line on the other are shown in Table 3. According to this, the aim 
was to reduce the poverty percent from 23.8 to 18 percent but this remained unsuccessful and the data was limited to 21.6 percent.

Table 3: Aims and progress of thirteenth plan period (2070/71-2072/73)

\begin{tabular}{|l|c|c|c|}
\hline Indicators & $\begin{array}{c}\mathbf{2 0 6 9 / 7 0} \\
\text { situation }\end{array}$ & Aim of $\mathbf{1 3}^{\text {th }}$ plan & Progress \\
\hline Annual average economic growth rate (\%) & 3.5 & 6.0 & 2.9 \\
\hline Agriculture sector average growth rate (\%) & 1.1 & 4.5 & 2.2 \\
\hline $\begin{array}{l}\text { Non-agriculture sector average growth rate } \\
\text { (\%) }\end{array}$ & 4.6 & 6.7 & 3.4 \\
\hline Annual average employment growth rate (\%) & 2.9 & 3.2 & 2.9 \\
\hline Population below poverty line (\%) & $\mathbf{2 3 . 8}$ & $\mathbf{1 8 . 0}$ & $\mathbf{2 1 . 6}$ \\
\hline Average age & 68.8 & 71.0 & 69.0 \\
\hline
\end{tabular}

Source: Fourteenth Plan (2073/74-2075/76), NPC, Kathmandu, Nepal.

\section{Long term Vision to Alleviate Poverty}

The $13^{\text {th }}$ plan $(2070 / 71-2072 / 73)$ and $14^{\text {th }}$ plan $(2073 / 74-2075 / 76)$ reduced the poverty percent to 21.6 and 18.7 percent respectively. Similarly, the 15th plan (2076/77-2080/81) targeted to reduce the poverty percent from 18.7 to 11.0 percent. In addition, the percent of people below poverty line is assumed to be zero by the year 2100/01 (Table 4).

Table 4: Long term Vision of Fifteenth Plan (2076/77-2080/81) Period for Prosperity

\begin{tabular}{|l|c|c|c|}
\hline Indicators & $\mathbf{2 0 7 4 / 7 5}$ (fact) & $\mathbf{2 0 8 0 / 8 1 ~ ( a i m ) ~}$ & $\mathbf{2 1 0 0 / 0 1 ~ ( a i m ) ~}$ \\
\hline Economic growth rate (\%) & 6.8 & 10.3 & 10.5 \\
\hline Per capita national income (US\$) & 1047 & 1595 & 12100 \\
\hline Below poverty line population (\%) & $\mathbf{1 8 . 7}$ & $\mathbf{1 1 . 0}$ & $\mathbf{0 . 0}$ \\
\hline Agriculture sector to GDP (\%) & 27.0 & 23.0 & 9.0 \\
\hline Non-agriculture sector to GDP (\%) & 73.0 & 77.0 & 91.0 \\
\hline Industry (\%) & 15.2 & 18.0 & 30.0 \\
\hline Services (\%) & 57.8 & 59.0 & 61.0 \\
\hline
\end{tabular}

Source: Fifteenth Plan (2076/77-2080/81), NPC, Kathmandu, Nepal.

The NLSS survey reported the percent of population below the poverty line in the year 1995/96, 2003/04 and 2010/11 were 41.8 percent, 30.9 percent and 25.2 percent 
respectively. The $13^{\text {th }}$ plan period $(2070 / 71-2072 / 73)$ and $14^{\text {th }}$ plan $(2073 / 74-2075 / 76)$ period reduced the poverty percent 21.6 and 18.7 percent respectively. Hence the trend of poverty reduction for population below the poverty line in various years is shown (Figure 4).

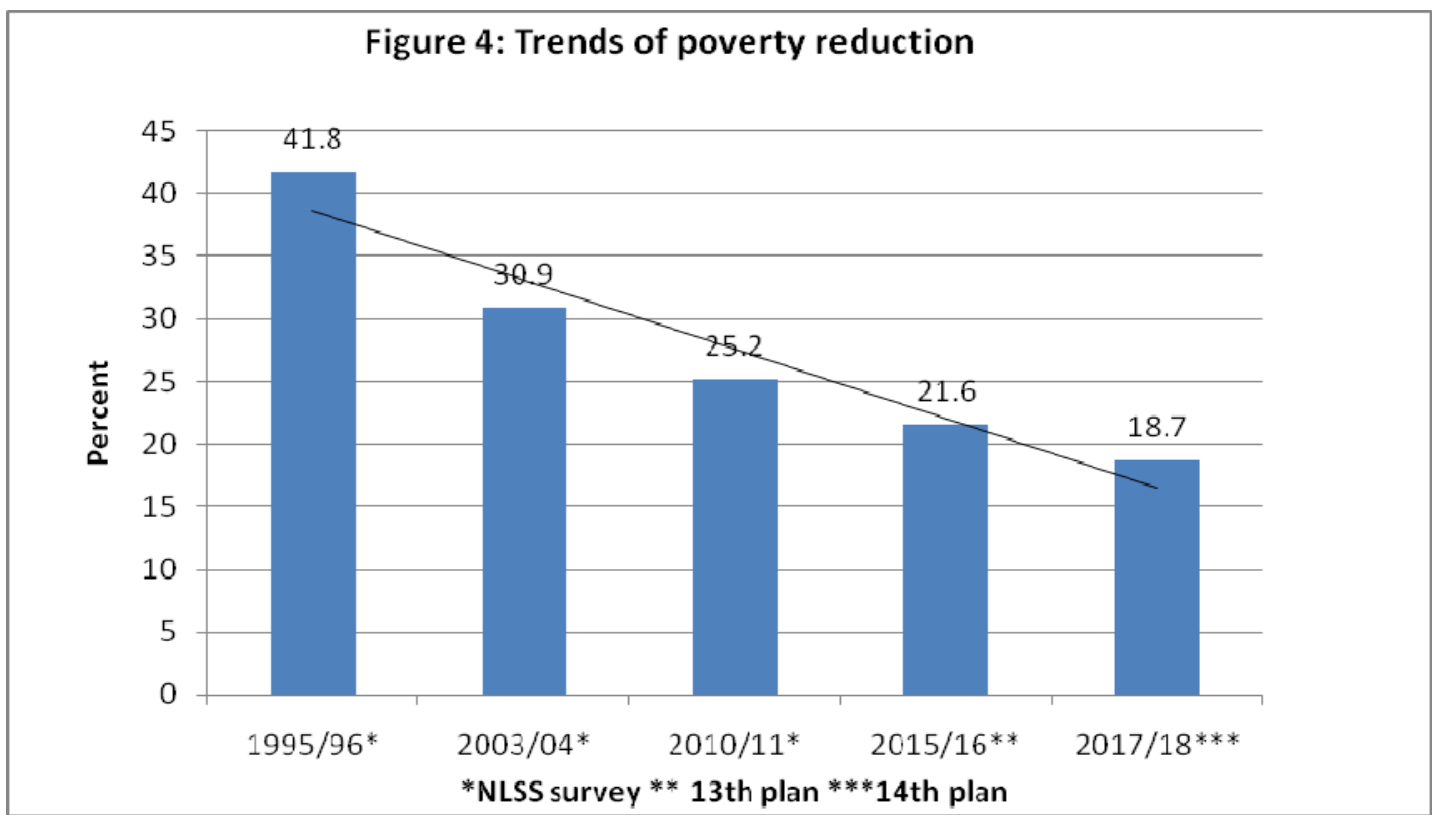

The Poverty Alleviation Fund of Nepal have targeted the absolutely poor people for poverty alleviation. They have initiated and conducted programmes that are inclusive of all religion and castes, transparent and aims towards the benefits of the society and its people. The funds that are contributed by various organizations are shown below (Table 5). It is estimated that an average of 2.49 percent of poverty decreased every year.

Table 5: Budget implementation by various community organizations (Rs. in thousand)

\begin{tabular}{|l|l|l|l|l|l|l|l|}
\hline $\begin{array}{l}\text { Fiscal } \\
\text { year }\end{array}$ & $\begin{array}{l}\text { Income } \\
\text { earn } \\
\text { programme }\end{array}$ & $\begin{array}{l}\text { Small } \\
\text { infrastructure } \\
\text { development } \\
\text { programme }\end{array}$ & $\begin{array}{l}\text { Newly } \\
\text { programme }\end{array}$ & \multicolumn{2}{|l|}{ Total } \\
\hline & & & & Total & $\begin{array}{l}\text { World } \\
\text { Bank } \\
\text { grant }\end{array}$ & $\begin{array}{l}\text { Trust fund } \\
\text { grant }\end{array}$ & $\begin{array}{l}\text { Nepal } \\
\text { Govt. } \\
\text { grant }\end{array}$ \\
\hline $2062 / 63$ & 155083 & 90730 & 138070 & 383883 & 317597 & - & 66286 \\
\hline $2063 / 64$ & 404332 & 76444 & 499113 & 979889 & 979889 & - & - \\
\hline $2064 / 65$ & 1274572 & 230652 & 46451 & 1551675 & 1551675 & - & - \\
\hline
\end{tabular}




\begin{tabular}{|l|l|l|l|l|l|l|l|}
\hline $2065 / 66$ & 971458 & 261798 & 27640 & 1260896 & 1260520 & - & 376 \\
\hline $2066 / 67$ & 1388289 & 426561 & 35749 & 1850599 & 1850599 & - & - \\
\hline $2067 / 68$ & 1526898 & 470910 & 11401 & 2009209 & 1720129 & - & 289080 \\
\hline $2068 / 69$ & 1445461 & 914485 & 24132 & 2384077 & 1661869 & 685642 & 36566 \\
\hline $2069 / 70$ & 1044414 & 591030 & 31630 & 1667075 & 1457013 & 175128 & 34934 \\
\hline $2070 / 71$ & 897021 & 742155 & 32882 & 1672059 & 1603579 & 23300 & 45180 \\
\hline $2071 / 72$ & 861770 & 490545 & 20048 & 1372362 & 1320977 & - & 51385 \\
\hline $2072 / 73$ & 1163488 & 396664 & 1247 & 1561399 & 1488065 & 19813 & 53521 \\
\hline $\begin{array}{l}2073 / 74 \\
*\end{array}$ & 162808 & 94215 & - & 257023 & 254352 & 2671 & - \\
\hline
\end{tabular}

Source: Economic Survey 2073/74, MOF, Kathmandu, Nepal.

With the aim of alleviating poverty completely by 2100/01, different programmes have been conducted mainly targeting the western hilly regions of Nepal under the poverty alleviation programme. Especially eight districts from the western region are focused and the details of the families and population residing there are given below (Table 6).

Table 6: WUPAP Implementation Districts, Households and Population

\begin{tabular}{|c|c|c|c|c|c|c|c|c|c|c|c|}
\hline Districts & $\begin{array}{c}\text { No. of } \\
\text { HHs }\end{array}$ & Male & Female & Total & $\begin{array}{c}\text { Benefit } \\
\text { ed } \\
\text { populat } \\
\text { ion (\%) }\end{array}$ & $\begin{array}{c}\text { Total } \\
\text { VDC }\end{array}$ & $\begin{array}{c}\text { Total } \\
\text { munici } \\
\text { pality }\end{array}$ & $\begin{array}{c}\text { WUPAP } \\
\text { impleme } \\
\text { nted } \\
\text { VDC }\end{array}$ & $\begin{array}{c}\text { Benefite } \\
\text { d VDC } \\
(\%)\end{array}$ & $\begin{array}{c}\text { Benef } \\
\text { itedH } \\
\text { Hs }\end{array}$ & $\begin{array}{c}\text { Benefit } \\
\text { ed } \\
\text { populat } \\
\text { ion }\end{array}$ \\
\hline Rolpa & 43757 & 103100 & 121406 & 224506 & 16.2 & 51 & 0 & 20 & 39.2 & 15.1 & 39673 \\
\hline Rukum & 41856 & 99159 & 109408 & 208567 & 15.0 & 43 & 0 & 20 & 46.5 & 22.5 & 51280 \\
\hline Dailekh & 48919 & 126990 & 134780 & 261770 & 18.9 & 55 & 1 & 20 & 36.3 & 20.5 & 58989 \\
\hline Jajarkot & 30472 & 85537 & 85767 & 171304 & 12.4 & 30 & 0 & 15 & 50.0 & 23.4 & 41819 \\
\hline Kalikot & 23013 & 68833 & 68115 & 136948 & 9.9 & 30 & 0 & 15 & 50.0 & 35.4 & 47686 \\
\hline Humla & 9479 & 25833 & 25025 & 50858 & 3.7 & 27 & 0 & 22 & 81.4 & 68.0 & 39191 \\
\hline Bajura & 24908 & 65806 & 69106 & 134912 & 9.8 & 27 & 0 & 18 & 66.7 & 47.0 & 71720 \\
\hline Bajhang & 33786 & 92794 & 102365 & 195159 & 14.1 & 47 & 0 & 23 & 48.9 & 36.6 & 81512 \\
\hline Total & 1384024 & 668052 & 715972 & 1384024 & 100.0 & 310 & 1 & 153 & 49.3 & 28.1 & 431870 \\
\hline
\end{tabular}

Source: Economic Survey 2073/74, MOF, Kathmandu, Nepal.

*WUPAP- Western Uplands Poverty Alleviation Project 


\section{Conclusion}

Poverty has been prevailing in Nepal since a long time. Its effect can be felt in every part of Nepal. The only difference is that its effect is more in some areas while it's low in other areas. The populations residing in rural areas are affected more. Also, two-third of the population of Nepal is dependent on agriculture. While this plays an important role on the economy it has its consequences on the earnings of the people. Nepal has failed to adopt modernized agriculture, so the population relying on agriculture are confronting unforeseeable circumstances. Hence, it is essential to make changes in the agricultural process and adopt modern ways. Non-agricultural sector too has to have development and create more employment opportunities. In addition, from the start of the $9^{\text {th }}$ plan, programmes that emphasize on poverty alleviation are conducted frequently. Similarly, activities that lead to the growth of economy are given priority; thus implemented.

Therefore, the $10^{\text {th }}$ plan aimed to achieve economic growth, improvement in providing service, prolongation of inclusive society etc. Execution of the plan will aid in reducing the poverty percent from 38 percent to 30 percent. Furthermore, until the end of the $12^{\text {th }}$ plan the percent of population below poverty line is found to be 24.5 percent. Keeping up with the same intensity, the $13^{\text {th }}$ plan (2070/71-2072/73) directed towards poverty reduction with 21.6 percent and 18.7 percent in the $14^{\text {th }}$ plan (2073/74-2075/76). Similarly, in the $15^{\text {th }}$ plan period (2076/77-2080/81) it was targeted to reduce the poverty percent from 18.7 to 11.0. By 2100/01 B.S. the poverty is assumed to be completely alleviated from Nepal. Hence, in order to achieve this completely for the sake of the people and the country, attempts from every sector are very important. As a result, prosperous Nepal will be attained.

\section{References}

ADB (2013), Country Poverty Analysis (Detailed). Asian Development Bank, Country Partnership Strategy: Nepal, 2013-2017.

Arora, R, C., (1986), Integrated Rural Development.

Bam, N., Thagurathi, R. K., and Neupane, D. (2016), Impact of Remittance on Household Income, Consumption and Poverty Reduction of Nepal.

CBS (2019), Report on the Nepal Labour Force Survey 2017/18. Central Bureau of Statistics, National Planning Commission Secretariat, Kathmandu. Nepal.

, (2014), Population Monograph of Nepal, Vol. 1: Population Dynamics. Central Bureau of Statistics, National Planning Commission Secretariat, Kathmandu. Nepal. , (2011), Nepal Living Standard Survey. Central Bureau of Statistics, National Planning Commission Secretariat, Kathmandu. Nepal. , (2011), National Population and Housing Census. Central Bureau of Statistics, National Planning Commission Secretariat, Kathmandu. Nepal. 
, (2011), Poverty in Nepal. Nepal Living Standard Survey III 2009/10, Brief Report.Central Bureau of Statistics, National Planning Commission Secretariat, Kathmandu. Nepal. , (2008), Nepal Labour Force Survey, Central Bureau of Statistics. National Planning Commission Secretariat, Kathmandu. Nepal.

, (2005), Poverty Assessment Results (Briefing Notes Presented at a National Workshop on NLSS Results Held in May 2005). Central Bureau of Statistics, National Planning Commission Secretariat, Kathmandu. Nepal. , (2004), Poverty Trends in Nepal (1995/96-2003/04). Central Bureau of Statistics, National Planning Commission Secretariat, Kathmandu. Nepal. , (2004), Nepal Living Standard Survey. Central Bureau of Statistics, National Planning Commission Secretariat, Kathmandu. Nepal. , (2003), Census of Manufacturing Establishments. Central Bureau of Statistics, National Planning Commission Secretariat, Kathmandu. Nepal. , (1998), Census of Manufacturing Establishments. Central Bureau of Statistics, National Planning Commission Secretariat, Kathmandu. Nepal. , (1996), Nepal Living Standard Survey. Central Bureau of Statistics, National Planning Commission Secretariat, Kathmandu. Nepal.

DFID (2013), Seasonal Dimensions of Poverty Vulnerability in Nepal, Summery Report. Department for International Development.

Ghosh, J. (2010), Poverty Reduction in China and India: Policy Implications of Recent Trends, DESA Working Paper No. 92.

IMF (2003), Nepal Poverty Reduction Paper, International Monetary Fund Country Report No. 03/305, The Tenth Plan, Poverty Reduction Strategy Paper, 2002-2007. National Planning Commission Secretariat, Kathmandu. Nepal.

MOF (2021), Economic Survey 2020/21. Ministry of Finance, Kathmandu. Nepal. , (2020), Economic Survey 2019/20. Ministry of Finance, Kathmandu. Nepal. , (2019), Economic Survey 2018/19. Ministry of Finance, Kathmandu. Nepal. , (2018), Economic Survey 2017/18. Ministry of Finance, Kathmandu. Nepal. , (2017), Economic Survey 2016/17. Ministry of Finance, Kathmandu. Nepal. , (2016), Economic Survey 2015/16. Ministry of Finance, Kathmandu. Nepal.

Nikku, B. and Azman A., (2014), Politics, Policy and Poverty in Nepal, International Journal of Social Work and Human Services Practice, Vol. 2, No. 2, pp. 1-9.

NPC (2019/20-2023/24), Fifteenth Plan Approach Paper. National Planning Commission, Kathmandu, Nepal.

NPC (2018), Nepal Multidimensional Poverty Index, Analysis Towards Action. National Planning Commission, Kathmandu, Nepal.

_. (2016/17-2018/19), Fourteenth Plan. National Planning Commission, Kathmandu, Nepal. , (2006), An Assessment of the Implementation of the Tenth Plan/Poverty Reduction Strategy Papers. National Planning Commission, Kathmandu, Nepal.

_. (1997-2002), Ninth Plan. National Planning Commission, Kathmandu, Nepal. 
NRB (2017), Macro Economic Indicators in Nepal. Nepal Rastra Bank, Kathmandu, Nepal. , (2019). Annual Report 2018/19. Nepal Rastra Bank, Kathmandu, Nepal. , (2017). Annual Report 2016/17. Nepal Rastra Bank, Kathmandu, Nepal. , (2016). Annual Report 2015/16. Nepal Rastra Bank, Kathmandu, Nepal. , (2016), Quarterly Economic Bulletin. Nepal Rastra Bank, Kathmandu, Nepal.

PAF (2016), Annual Report 2015/16, Poverty Alleviation Fund, Kathmandu, Nepal.

Parajuli, D., Acharya, G., Chaudhury, N., and Thapa, B .B. (2012), Impact of Social Fund on the Welfare of Rural Households Evidence from the Nepal Poverty Alleviation Fund, The World Bank, South Asia Region: Sustainable Development Unit and Human Development Unit, Policy Research Working Paper 6042.

Pyakurel, K. N., (1994), Technical Paper on Poverty in Nepal. National Planning Commission, Kathmandu. Nepal.

Sharma, S., (2005), Macro-economic Policies and Poverty Reduction in Nepal. NLA, Kathmandu. Nepal.

, (2002), Land Tenure and Poverty in Nepal. Kathmandu, MIMAP-Nepal.

Sigdel, B. D., (2020), Economic Impact of Covid-19 on Employment, Migration, Remittance and Poverty in Nepal: Policies Responses.

Uemastu, H., Shidiq, A. R., and Tiwari S. (2016), Trends and Drivers of Poverty Reduction in Nepal, A Historical Perspective, Policy Research Working Paper 7830. World Bank Group. UNDP (2014), Nepal Human Development Report. Kathmandu. Nepal. , (2004), The Macro-economics of Poverty Reduction: The Case Study of Nepal. United Nations Development Programme, Kathmandu, Nepal.

WB (2017), Nepal Poverty Alleviation Fund. World Bank, Independent Evaluation Group. WB (1999), Nepal - Poverty in Nepal at the Turn of the Twenty-First Century. World Bank. WTO (2018), Trade and Poverty Reduction: New Evidence of Impacts in Developing Countries. WTO and WB (2015), The Role of Trade in Ending Poverty. Joint Publication by the World Trade Organization and World Bank. 